\title{
Evaluation Activity of Some Antimicrobial Agents in Reduction Microbial Load and Their Impact on Vase Life of Asparagus aethiopicus $\mathbf{L}$.
}

\author{
Abdel-Rahman, T.F.M.
}

Plant Pathology Research Institute, Agricultural Research

Center, 12619, Giza, Egypt.

The short vase life is a major problem in the Asparagus aethiopicus leafy cut stem industry. The present study showed that several bacterial and fungal species were found to be associated with $A$. aethiopicus cut wilted stems and their vase life. This included six bacterial species, i.e., Bacillus subtilis, Bacillus sp., Pseudomonas sp., Streptococcus sp., Streptomyces sp. Streptobacillus sp. and also five fungal species, i.e., Alternaria alternata, Fusarium oxysporum, $F$. solani, Aspergillus flavus and A. niger. However, Pseudomonas sp. and $F$. oxysporum were the most frequent bacterial and fungal microorganisms. Three tested antimicrobial agents, i.e., 8-hydroxy quinoline citrate (8-HQC), sodium hypochlorite and citric acid significantly reduced number of bacterial and fungal proliferation in the different vase treatments where stems basal ends were dipped in them and this effect was increased with increasing their concentrations. However, 8-HQC at $200 \mathrm{ppm}+$ oxytetracycline hydrochloride $(1000 \mathrm{ppm})$ showed reduction percentages of 84.29 and $51.72 \%$ of bacterial and fungal numbers, respectively. Also, sodium hypochlorite at $10 \mathrm{ppm}+$ oxytetracycline hydrochloride $(1000 \mathrm{ppm})$ recorded bacterial and fungal reductions that reached 85.25 and $42.44 \%$, respectively. This was followed by citric acid $(1000 \mathrm{ppm})+$ oxytetracycline hydrochloride $(1000 \mathrm{ppm})$ which showed 83.31 and $28.32 \%$, reductions of bacterial and fungal numbers while antimicrobial agents' treatments without oxytetracycline hydrochloride showed lower reduction effect. All antimicrobial agents' treatments succeeded to decrease weight loss and enhanced water uptake and vase life of the treated A. aethiopicus cut stems and this effect was increased with increasing their concentrations. Meanwhile, treatment with the mixture of 8 -HQC $(200 \mathrm{ppm})+$ oxytetracycline $(1000 \mathrm{ppm})$ was the most effective treatment in decreasing cut stem weight loss to be low as $4.05 \%$ compared to $44.37 \%$ for the untreated control. Also, this treatment enhanced water uptake and vase life to be as high of $44.90 \mathrm{~g}$ and 14.50 days compared to $16.81 \mathrm{~g}$ and 5.44 days of the control treatment in the previous parameters, respectively. This was followed by the mixture of sodium hypochlorite $(10 \mathrm{ppm})+$ oxytetracycline hydrochloride $(1000 \mathrm{ppm})$ and citric acid at $(1000 \mathrm{ppm})+$ oxytetracycline hydrochloride (1000 ppm) treatments.

Keywords: Asparagus aethiopicus, oxytetracycline hydrochloride, Fusarium oxysporum, Bacillus subtilis, microbial load, vase life 
Asparagus aethiopicus L. is belonging to the Asparagaceae family (Gandipilli and Geddada 2018). It is extensively utilized by florists in flowers ornamentation. Its ornamental foliage is a perfect complementary background to most other flowers designs. It serves as an amazing greenery in delicate flower bouquets, and it can be applied as cascading central points in great designs (Safeena et al., 2019).

Its leafy cut stems have been popular in recent years in Egypt as a filling material in vases and rose bouquets. However, they only have a vase life of 4-6 days at room temperature which is much shorter than many other plant filling materials Safeena $e t$ al., 2014. Therefore, there is a commercial demand for protracting and elongating their foliage vase life (Shabanian et al., 2018). It has been frequently reported that several bacterial and fungal proliferations are associated with such reduction in vase life (Ichimura et al., 2016, Kampowski et al., 2018 and Gandipilli and Geddada, 2018). Bacterial and fungal species that reproduce in the vase solution and cut stems prevent water uptake and thus lowering vase life (Balestra et al., 2005 and Ferrante et al., 2007). Pathogens (fungal and/or bacteria ones) growth in the vase solution causes a physical objection of xylem then reduces the uptake of water ended to senescence. Also, Coutinho and Wingfield (2017), Younis et al. (2018) and Zeiss et al. (2019) mentioned that the presence of pathogenic agents often leads to vascular siege in cut stems, damaging of the important cellular processes and accelerates the death of the infected stems. Symptoms caused by the pathogenic agent included hindered wood texture of cut stems that lowering their lifetime and causing insufficient water uptake due to physical blockage of xylem vessels.

So, several antifungal and antibacterial compounds that indirectly enhance water flowing in the xylem in preservative solutions like 8-hydroxyquinoline citrate, citric acid and sodium hypochlorite were proposed and they have been used to attain the best postharvest quality and vase life in several cut flowers and foliage Hashemabadi et al., 2015; Rida et al., 2016; Balieiro et al.; 2018, He et al., 2018; Kantharaj et al., 2018; Sarhan et al., 2018 and Safeena et al., 2019.

The present study, therefore, focused on potential of microbial load proliferation on the cut stems vase life of A. aethiopicus and the efficacy of some safe materials to control the associated pathogens and to attain the quality and vase life of $A$. aethiopicus.

\section{Materials and Methods}

The present study was conducted at Research Branch, Plant Pathology Research Institute, Ornamental, Medicinal and Aromatic Plant Diseases Research Department, El-Sabihia Agricultural Research Station Alexandria. Samples of $A$. aethiopicus showing symptoms of wilt were collected from different vases in different places in Alexandria during 2018 for isolation and identification of the associated fungal and bacterial species.

Egypt. J. Phytopathol., Vol. 47, No. 2 (2019) 
EVALUATION ACTIVITY OF SOME ANTIMICROBIAL AGENTS .. 159

1. Isolation and identification of the associated bacteria and fungi:

One $\mathrm{cm}$ long segments were cut from the leafy cut stem ends in each flask for isolation of the associated fungal and bacterial species as follows:

\subsection{Isolation and identification of the associated fungi:}

Samples segment of the were thoroughly washed for several times under running water, cut into small pieces, rinsed in sterilized distilled water, dried between two folds of sterilized filter paper and cultured on PDA in petri plates. Inoculated plates were kept at $26^{\circ} \mathrm{C} \pm 2$ for five days. The developed fungal colonies were purified using single spore or hyphal tip techniques and maintained on slant PDA (Al-Jaradi et al., 2018). The isolated fungi were identified using the morphological characteristics of mycelia and spores according to Barnett and Hunter (1986) and Sneh et al. (1991). Identification of the isolated fungi was confirmed by the staff members of Department of Mycology, Plant Disease Survey' and Plant Pathology Research Institute, ARC, Giza, Egypt. Percentage of frequencies $(\%)$ of the recovered fungal species were then calculated according to, Braithwaite et al. (2006) as follows:

$$
\text { Frequency }(\%)=\frac{\text { Number of detected fungal colonies }}{\text { Total fungal colonies }} \times 100
$$

\subsection{Isolation and identification of the associated bacteria:}

According to Harrigan and McCance (1996), segments were washed several times with distilled water, then ground in a mortar with $10 \mathrm{ml}$ sterile normal saline solution, strained in cheese cloth, and $0.1 \mathrm{ml}$ of the filtrate was spread on nutrient agar in plates, incubated at $31 \pm 1^{\circ} \mathrm{C}$ for $24 \mathrm{~h}$. Developed bacterial colonies were counted according to the morphological characteristics (Jowkar et al., 2012) and streaked onto new nutrient agar plates until separated colonies were obtained. Pure cultures of the bacterial species were maintained in nutrient agar slants and were identified according to Harrigan and McCance (1996), Benson (2002) and Naing et al. (2017) by the Agricultural Laboratory (Agro Lab), Sadat City, Egypt. Frequency of the associated bacterial species were calculated as mean CFU (Colony Forming Unit/ milliliter) Bacteria / ml, estimated by the serial dilution method Reynolds (2015).

2. Pathogenicity tests for the recovered fungal and bacterial species:

According to Younis et al. (2014), matured outwardly healthy cut stems of $A$. aethiopicus (freshly cut stems with $60-70 \mathrm{~cm}$ long stems) were obtained from a commercial well-known nursery in Alexandria. Cut stems were warped in tissue paper and taken to the laboratory, then slanting cuts $(2-\mathrm{cm})$ were made for cut stems under the running tap water for better absorption of vase solution, and lower leaflets were stripped off, sterilized by $1 \%$ sodium hypochlorite for three minutes and washed several times with sterile distilled water. Six A. aethiopicus cut stems were prepared for each treatment (in three glass vases, 2 in each) and each vase 
contained $500 \mathrm{ml}$ of sterile distilled water with $10 \mathrm{~g}$ sucrose where the basal $5-\mathrm{cm}$ of the cut stems were dipped. All vases were sterilized by immersing in 3\% sodium hypochlorite for $20 \mathrm{~min}$ washed several times with distilled water then inverted and left to dry. All treated cut stems were kept at room temperature of $21 \pm 2^{\circ} \mathrm{C}$, relative humidity of $63 \pm 3 \%$, and $12 \mathrm{~h} /$ day cool white fluorescent light lamps. All vases were covered with cotton plug to block water evaporation and to reduce the entry of bacteria and fungi from the surrounding air.

\subsection{Pathogenicity tests of fungal species:}

The tested isolates were cultured on PDA at $26^{\circ} \mathrm{C} \pm 2$ for ten days. The spores were scraped from the surface of the culture and introduced into $10 \mathrm{ml}$ of sterile distilled water. Concentration was determined by using Haemocytometer slide. The suspension was adjusted to the concentration of $10^{6}$ spores $/ \mathrm{ml}$ and $5 \mathrm{ml}$ of the spore suspension were added to each vase which contained $500 \mathrm{ml}$ sterile distilled with $10 \mathrm{~g}$ sucrose. Control vases were inoculated with $5 \mathrm{ml}$ sterile distilled with $10 \mathrm{~g}$ sucrose. After 24 hours of inoculation, six A. aethiopicus cut stems (2 in each vase), prepared as previously mentioned, were dipped in vase solution where the basal $5-\mathrm{cm}$ of the cut stems were covered. All vases were kept at room temperature as previously mentioned. Plants in vases were monitored daily and when wilt symptoms were developed (three days after dipping basal leafy stem cuts in inoculated vase solution), disease severity for each fungal species was calculated. To fulfill Koch's postulates, re-isolations were conducted and identification of the recovered fungi was performed as previously mentioned where confirmed the associated fungal species.

\subsection{Pathogenicity tests of bacterial species:}

According to Li et al. (2012) and Rafi and Ramezanian (2013), pathogenicity tests were performed by using bacterial cultures grown at $31 \pm 1^{\circ} \mathrm{C}$ for $24 \mathrm{~h}$. on nutrient agar (NA). Each bacterial species was suspended in sterile distilled water and bacterial concentration was adjust to $10^{8} \mathrm{CFU} / \mathrm{ml}$, using the serial dilution method pour plate technique according to Jowkar et al. (2012) Reynolds (2015). Pathogenicity tests were performed in the glass vases containing $500 \mathrm{ml}$ sterile distilled water with $10 \mathrm{~g}$ sucrose. All vase solutions were inoculated with $5 \mathrm{ml}$ bacterial suspension $\left(10^{8} \mathrm{CFU} / \mathrm{ml}\right)$ and control vases were inoculated with $5 \mathrm{ml}$ sterile distilled water with $10 \mathrm{~g}$ sucrose. After 24 hours of inoculation, six $A$. aethiopicus cut stems ( 2 in each vase) were dipped in vase solution where the basal $5 \mathrm{~cm}$ of the cut stems were covered. All vases were kept at room temperature and all vases were covered with cotton plug as previously mentioned. Cut stems in vases were monitored daily and when wilt symptoms were developed (three days after dipping basal leafy stem cuts in inoculated vase solution), disease severity for each bacterial species was calculated. To fulfill Koch's postulates, re-isolations were conducted, and identification of the recovered bacteria was performed as previously mentioned where confirmed the associated bacterial species.

Egypt. J. Phytopathol., Vol. 47, No. 2 (2019) 
EVALUATION ACTIVITY OF SOME ANTIMICROBIAL AGENTS .. 161

Disease assessment:

According to Vakalounakis and Fragkiadakis (1999), five disease ratings were assigned as follows: $0=$ No symptoms; $1=$ Light yellowing of leaves, light or moderate rot on basal stem; 2 = Moderate or severe yellowing of leaves and severe rot basal stem, 3 = Moderate wilting and desiccation, curling, necrosis and rot basal stems, 4= Dead by severe wilting, yellowing, desiccation, graying, curling, and necrosis and leaves drop. Then, percentage of disease severity (DS\%) was calculated according to the formula adopted by Song et al. (2004).

Disease severity $(\mathrm{DS} \%)=\frac{\sum(\text { scale } \times \text { number of plants infected })}{\text { highest scale } \mathrm{X} \text { total number of plants }} \times 100$

3. Effect of the tested antimicrobial agents to control wilt of A. aethiopicus cut

stems under natural infection:

Three materials i.e., sodium hypochlorite (SHC) 40\% ( $\mathrm{NaOCl}$ ), citric acid (CA) pure $\left(\mathrm{C}_{6} \mathrm{H}_{8} \mathrm{O}_{7}\right)$ and pure 8-hydroxy quinoline citrate (8-HQC) singly and at different concentrations as well as their mixtures with the antibiotic oxytetracycline hydrochloride (Ox) were tested in treatments according to Kantharaj et al. (2018), as follows:

\section{Treatments}

$\mathbf{T}_{1} \quad$ Sodium hypochlorite (SHC) at 2, 5 and $10 \mathrm{ppm}$.

$\mathbf{T}_{2} \quad$ Citric acid (CA) at 200, 500 and $1000 \mathrm{ppm}$.

T3 $_{3}$ 8-hydroxy quinoline citrate (8-HQC) at 50, 100 and $200 \mathrm{ppm}$.

T4 SHC (at 2, 5 and $10 \mathrm{ppm})+$ oxytetracycline hydrochloride (Ox) at (1000 ppm).

$\mathbf{T}_{5} \quad \mathrm{CA}$ (at 200, 500 and $1000 \mathrm{ppm}$ ) +Ox (at $1000 \mathrm{ppm}$ ).

T6 8 -HQC (at 50, 100 and $200 \mathrm{ppm}$ ) + Ox (at $1000 \mathrm{ppm}$ ).

Control distilled water

All agents were dissolved in tap water with $10 \mathrm{~g} / \mathrm{l}$ sucrose, each vase contained $500 \mathrm{ml}$ of the tested antimicrobial agent solution. A. aethiopicus cut stems were prepared, and the experiment was conducted as previously mentioned under pathogenicity test. Then, A. aethiopicus cut stems in vase treatments were monitored for any wilt symptoms. All antimicrobial agents were obtained from ElGomhouria Company, Alexandria branch.

3.1. Effect of the teste materials on bacterial and fungal proliferation in A. aethiopicus vase solution:

When wilt symptoms began to appear on the control, a one $\mathrm{ml}$ of vase solution from all replicates was collected, five days after dipping the basal portion of cut stems in the different antimicrobial agents treatments of solutions. Then, the serial dilution method-pour plate technique was applied to count bacteria on nutrient agar according to Fung (2009) and Reynolds (2015) and also, the detected fungal colonies were also counted according to Jowkar et al. (2012). However, bacterial 
count at the $5^{\text {th }}$ day of the treatment was below the limit to apply the counting equation (Fung, 2009), so, samples were taken again from control and all treatments on the seventh day for bacterial and fungal counting. After the serial dilutions, one $\mathrm{ml}$ of the fifth dilution was plated onto nutrient agar in plates. Then, inoculated plates were incubated at $30 \pm 1^{\circ} \mathrm{C}$ for $24 \mathrm{~h}$. Number of bacteria was counted through the number of colonies formed after incubation and expressed as Colony Forming Units/ml (CFU/ml). Reduction percentage ( $\mathrm{R} \%)$ in bacterial and fungal colonies was calculated according to Ferreira et al. (1991) as follows:

$$
\text { Reduction } \%(\mathrm{R} \%)=\frac{\text { Control- Treatment }}{\text { Control }} \times 100
$$

3.2. Effect of antimicrobial agents on bacterial and fungal occurrence in $A$. aethiopicus cut stems:

On the seventh day of treatment, one cm long segments were cut from the leafy cut stem ends in each vase treatment for isolation of the accompanied bacterial and fungal species as previously mentioned according to Li et al. (2012), Rafi and Ramezanian (2013) and Jowkar et al. (2012). Occurrence (\%) of the associated fungal species was calculated according to Braithwaite et al. (2006), while occurrence of the associated bacteria was assigned as + and - according to Reynolds (2015).

3.3. Effect of antimicrobial agents on physiology and vase life of A. aethiopicus cut stems:

At the end of experiment, after 14 days of dipping cut stems in antimicrobial agents treatments, the following assessments were conducted According to Safeena et al. (2014), Hashemabadi et al. (2015) and Amin (2017) as follows:

$$
\text { Cut stems weight loss }(\mathrm{g})=\frac{\text { Initial fresh weight }- \text { Final fresh weight }}{\text { Initial fresh weight }} \times 100
$$

Cut stem water uptake $(g)$ :

It is the difference between the weight of the vase solution at the end of the vase life and weight of the vase solution at the beginning of trial.

Cut stem vase life (days):

Vase treatments with leafy cut stems were monitored daily and foliage vase life was recorded as the number of days until $20 \%$ of the foliage showed symptoms of wilting, yellowing, desiccation, graying, curling, and necrosis and leaves drop.

\section{Statistical analysis:}

The obtained data were statistically analyzed using Statistix program, and means comparisons were conducted using least significance difference (LSD) at 5\% level of significance according to Snedecor and Cochran (1989). Pearson's correlation coefficient was conducted using Excel, version, 2016.

Egypt. J. Phytopathol., Vol. 47, No. 2 (2019) 
EVALUATION ACTIVITY OF SOME ANTIMICROBIAL AGENTS .. 163

\section{Results}

1. Fungal and bacterial species associated with A. aethiopicus vase wilt.

Data presented in Table (1) show that five fungal species i.e., Alternaria alternata, Aspergillus flavus, A. niger, Fusarium oxysporum and $F$. solani, were found to be associated with A. aethiopicus leafy cut stem wilt in the surveyed vases. Also, six bacterial species, i.e., Bacillus subtilis, Bacillus sp., Pseudomonas sp., Streptococcus sp., Streptomyces sp., and Streptobacillus sp. were also associated with A. aethiopicus leafy cut stem vase wilt.

However, Fusarium oxysporum was the most frequent and constituted $32.30 \%$ of the surveyed plants. Also, all bacteria spp., were the most frequent colonies and recovered with mean $\mathrm{CFU}$ number of $105.33 \times 10^{5}$ bacterial species, respectively. (Table 1).

Table 1. Frequency of fungi and bacterial species associated with $A$. aethiopicus vase wilt.

\begin{tabular}{lcc}
\hline \multicolumn{1}{c}{ Fungal species } & $\begin{array}{c}\text { Frequency } \\
(\%)\end{array}$ & Bacterial species \\
\hline Alternaria alternata & $25.16^{*} \mathrm{~b}$ & Bacillus subtilis \\
Aspergillus flavus & $10.32 \mathrm{~d}$ & Bacillus sp. \\
A. niger & $14.21 \mathrm{~cd}$ & Pseudomonas $s p$. \\
Fusarium oxysporum & $32.30 \mathrm{a}$ & Streptococcus $s p$. \\
F. solani & $18.01 \mathrm{c}$ & Streptomyces $s p$. \\
- & - & Streptobacillus $s p$. \\
\hline Total & 100.00 & The total number of bacteria $105.33 \times 10^{5} \mathrm{CFU}^{* *}$ \\
\hline LSD. at 0.05 & 5.61 & - \\
\hline
\end{tabular}

*Values followed by different letter (s) are significantly different at $5 \%$ level

$* * \mathrm{CFU}$ (Colony Forming Unit/ milliliter) = Bacteria $/ \mathrm{ml}$, estimated by the serial dilution method.

2- Pathogenicity of the recovered fungal and bacterial species:

Data in Table (2) show that all fungal and bacterial species investigated were able to induce infection on the inoculated A. aethiopicus leafy cut stems with different severity degrees. The developed vase wilt disease severity (DS) with the tested fungal species ranged between 45.00 and $90.00 \%$ while DS with the tested bacterial species ranged between 35.00 and $86.67 \%$ for the tested bacterial species. However, $F$. oxysporum was the most virulent and showed $90.0 \%$ DS, followed by A. alternata which caused $87.5 \%$ DS and $F$. solani with $59.17 \%$ DS. Meanwhile, Streptomyces sp. was the most virulent tested bacterial species that showed the highest wilt DS, values being $86.67 \%$ followed by Pseudomonas sp. and Streptococcus sp. with 65.0 and $61.67 \%$ DS, respectively (Table 2). 
Table (2): Mean vase wilt disease severity on Asparagus aethiopicus leafy cut stems during pathogenicity.

\begin{tabular}{lclc}
\hline \multicolumn{2}{c}{ Bacterial species } & \multicolumn{2}{c}{ Fungal species } \\
\hline Bacillus subtilis & $35.00 * \mathrm{c}$ & Alternaria alternata & $87.50 \mathrm{a}$ \\
Bacillus sp. & $35.83 \mathrm{c}$ & Aspergillus flavus & $51.67 \mathrm{bc}$ \\
Pseudomonas sp. & $65.00 \mathrm{~b}$ & A. niger & $45.00 \mathrm{c}$ \\
Streptococcus sp. & $61.67 \mathrm{~b}$ & Fusarium oxysporum & $90.00 \mathrm{a}$ \\
Streptomyces sp. & $86.67 \mathrm{a}$ & F. solani & $59.17 \mathrm{~b}$ \\
Streptobacillus sp. & $37.50 \mathrm{c}$ & - & - \\
Control & 0.00 & & 0.00 \\
Overall mean & $53.61 \mathrm{~B}$ & Overall mean & $59.72 \mathrm{~A}$ \\
\hline & 7.28 & & 10.16 \\
LSD. at 0.05 & & & 3.56 \\
\end{tabular}

** Values followed by different letter (s) are significantly different at 5\% level.

3. Effect of antimicrobial agents on controlling A. aethiopicus vase wilt:

3.1. Effect of antimicrobial agents on bacterial and fungal numbers in A. aethiopicus vase solutions:

Data presented in Table (3) show that all tested antimicrobial agents caused significant reduction in the number of bacterial and fungal proliferation in vase solutions of the different treatments, however, this effect was more pronounced with mixing antimicrobial agents with oxytetracycline hydrochloride (1000 ppm). Meanwhile, 8-hydroxy quinoline citrate (8-HQC) at $200 \mathrm{ppm}+$ oxytetracycline hydrochloride (1000 ppm) showed reduction percentages of 84.29 and $51.72 \%$ in bacterial and fungal numbers, respectively. Also, sodium hypochlorite (SHC) at 10 $\mathrm{ppm}+$ oxytetracycline hydrochloride $(1000 \mathrm{ppm})$ recorded reduction in the numbers of bacteria and fungi that reached 85.25 and $42.44 \%$, respectively. This was followed by citric acid (CA) at $(1000 \mathrm{ppm})+$ oxytetracycline hydrochloride (1000 ppm) which showed 83.31 and $28.32 \%$, reduction in bacterial and fungal numbers, respectively while the remaining treatments showed lower effect. Also, it is evident from Figure (1) that all tested antimicrobial agents succeeded in decreasing the associated bacterial and fungal proliferation and the associated A. aethiopicus cut stem wilt.

Egypt. J. Phytopathol., Vol. 47, No. 2 (2019) 
EVALUATION ACTIVITY OF SOME ANTIMICROBIAL AGENTS .. 165

Table (3): Effect of antimicrobial agents on bacterial and fungal numbers in vase solutions with Asparagus aethiopicus leafy cut stems, 7 days after dipping the basal stem in vase treatment solutions under natural infection.

\begin{tabular}{|c|c|c|c|c|c|c|c|}
\hline & \multirow{2}{*}{ Treatment } & \multicolumn{3}{|c|}{ Number of bacteria } & \multicolumn{3}{|c|}{$\begin{array}{l}\text { Number of detected fungal } \\
\text { colonies }\end{array}$} \\
\hline & & $\begin{array}{c}\text { Number } \\
\times 10^{5} \\
(\mathrm{CFU} / \mathrm{ml})\end{array}$ & $\begin{array}{l}\text { Reduction } \\
(\%)\end{array}$ & $\begin{array}{l}\text { Mean of } \\
\text { Reduction } \\
(\%)\end{array}$ & Number & $\begin{array}{l}\text { Reduction } \\
\quad(\%)\end{array}$ & $\begin{array}{l}\text { Mean of } \\
\text { Reduction } \\
(\%)\end{array}$ \\
\hline \multirow{3}{*}{ SHC } & $2 \mathrm{ppm}$ & $40.87 \mathrm{bc}^{* *}$ & 48.01\# & & $17.20 \mathrm{~b}$ & 09.88 & \\
\hline & $5 \mathrm{ppm}$ & $33.57 \mathrm{de}$ & 57.29 & 60.25 & $17.11 \mathrm{~b}$ & 10.47 & 10.66 \\
\hline & $10 \mathrm{ppm}$ & $19.30 \mathrm{gh}$ & 75.45 & & $16.89 \mathrm{bc}$ & 11.63 & \\
\hline \multirow{3}{*}{ CA } & $200 \mathrm{ppm}$ & $36.00 \mathrm{~cd}$ & 55.54 & & $18.22 \mathrm{ab}$ & 05.75 & \\
\hline & $500 \mathrm{ppm}$ & $45.37 \mathrm{~b}$ & 43.97 & 55.08 & $18.11 \mathrm{ab}$ & 06.32 & 06.32 \\
\hline & $1000 \mathrm{ppm}$ & 27.73 ef & 65.75 & & $18.00 \mathrm{ab}$ & 06.90 & \\
\hline \multirow{3}{*}{ 8-HQC } & $50 \mathrm{ppm}$ & $21.67 \mathrm{fg}$ & 72.33 & & $15.44 \mathrm{~cd}$ & 19.19 & \\
\hline & $100 \mathrm{ppm}$ & $36.87 \mathrm{~cd}$ & 52.92 & 67.75 & $15.11 \mathrm{de}$ & 20.93 & 20.54 \\
\hline & $200 \mathrm{ppm}$ & $17.23 \mathrm{ghi}$ & 77.99 & & $15.00 \mathrm{de}$ & 21.51 & \\
\hline \multirow{3}{*}{ SHC } & $2 \mathrm{ppm}+\mathrm{Ox}$ & $14.13 \mathrm{hi}$ & 82.49 & & $11.78 \mathrm{f}$ & 38.37 & \\
\hline & $5 \mathrm{ppm}+\mathrm{Ox}$ & $13.70 \mathrm{i}$ & 83.02 & 83.59 & $11.56 \mathrm{f}$ & 39.53 & 40.12 \\
\hline & $10 \mathrm{ppm}+\mathrm{Ox}$ & $11.90 \mathrm{i}$ & 85.25 & & $11.00 \mathrm{fg}$ & 42.44 & \\
\hline \multirow{3}{*}{ CA } & $200 \mathrm{ppm}+\mathrm{Ox}$ & $33.83 \mathrm{de}$ & 54.83 & & $13.89 \mathrm{e}$ & 27.75 & \\
\hline & $500 \mathrm{ppm}+\mathrm{Ox}$ & $16.33 \mathrm{ghi}$ & 78.19 & 72.11 & $13.88 \mathrm{e}$ & 27.75 & 27.94 \\
\hline & $1000 \mathrm{ppm}+\mathrm{Ox}$ & $12.50 \mathrm{hi}$ & 83.31 & & $13.78 \mathrm{e}$ & 28.32 & \\
\hline \multirow{3}{*}{ 8-HQC } & $50 \mathrm{ppm}+\mathrm{Ox}$ & $14.10 \mathrm{hi}$ & 81.79 & & $09.89 \mathrm{gh}$ & 48.85 & \\
\hline & $100 \mathrm{ppm}+\mathrm{Ox}$ & $13.43 \mathrm{hi}$ & 82.65 & 82.91 & $09.50 \mathrm{gh}$ & 50.57 & 50.38 \\
\hline & $200 \mathrm{ppm}+\mathrm{Ox}$ & $12.17 \mathrm{i}$ & 84.29 & & $09.33 \mathrm{~h}$ & 51.72 & \\
\hline Overall & 1 Mean control & $78.48 \mathrm{a}$ & & & $19.20 \mathrm{a}$ & & \\
\hline & SD. at 0.05 & 6.88 & & & 1.45 & & \\
\hline
\end{tabular}

SHC $=$ Sodium hypochlorite, $\mathrm{CA}=$ Citric acid, 8 -HQC $=8$-hydroxy Quinoline citrate and $\mathrm{Ox}=$ Oxytetracycline hydrochloride antibiotic (at $1000 \mathrm{ppm}$ )

*CFU (Colony Forming Unit/milliliter) = Bacteria/ml, estimated by serial dilution method.

** Means followed by different letter (s) are significantly different at 5\% level. 


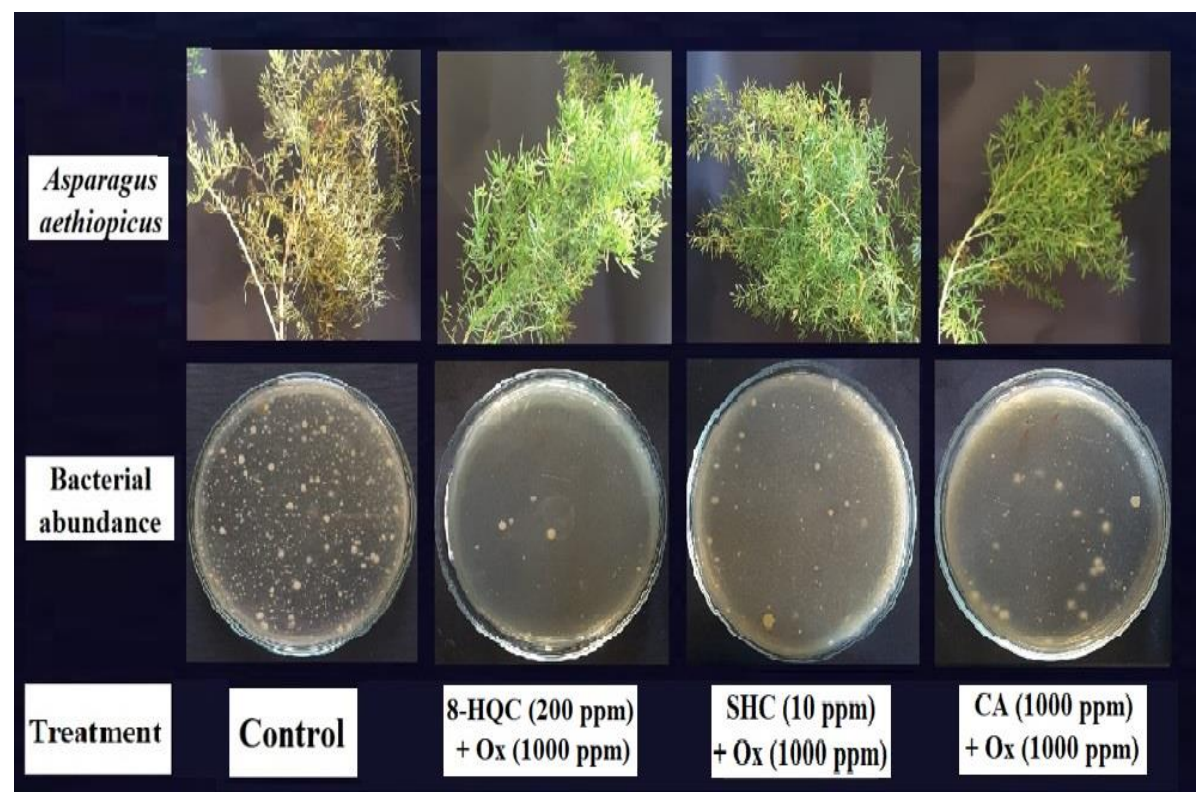

Figure (1): Effect of 8-hydroxy quinoline citrate at 200 ppm + oxytetracycline hydrochloride (1000 ppm), sodium hypochlorite at $10 \mathrm{ppm}+\mathrm{Ox}($ at $1000 \mathrm{ppm})$ and citric acid at $1000 \mathrm{ppm}+\mathrm{Ox}(1000 \mathrm{ppm})$ on Asparagus aethiopicus vase disorder caused by bacterial and fungal, and proliferation bacterial on nutrient agar.

Concerning the associated bacterial species, data in Table (4) show that six species of bacteria were isolated and identified from the collected samples. These associated detected species were Bacillus subtilis, Bacillus sp., Pseudomonas sp., Streptococcus sp., Streptomyces sp. and Streptobacillus sp. However, occurrence of these species was differed with the different treatments' where Bacillus subtilis, Pseudomonas sp. were the most frequent bacteria over the different treatments. Meanwhile, while the six bacterial species were occurred in control and in CA treatments, only two bacterial species, i.e., Bacillus subtilis and Pseudomonas sp. were occurred in 8-HQC + ox treatment (Table 4).

Regarding the associated fungal species, data in Table (5) show that five fungal species were found to be associated with A. aethiopicus leafy cut stem wilt where Alternaria alternata and $F$. oxysporum were the most frequent fungi over the different treatments. Moreover, data indicated that 8-HQC + Ox treatments showed the lowest mean fungal frequencies for all detected fungal species. However, the 8HQC $200 \mathrm{ppm}+$ Ox treatment was the most effective to inhibit the associated fungi and showed the lowest fungal frequencies for all species (Table 5).

Egypt. J. Phytopathol., Vol. 47, No. 2 (2019) 
Table (4): Effect of antimicrobial agents on the occurrence of the associated bacterial species in Asparagus aethiopicus cut stem in treated vases under natural infection.

\begin{tabular}{|c|c|c|c|c|c|c|c|}
\hline & Treatment & 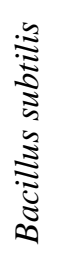 & $\begin{array}{c}\dot{0} \\
\tilde{n} \\
\underset{\Xi}{\Xi} \\
\underset{0}{0}\end{array}$ & 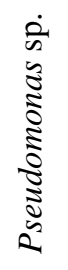 & 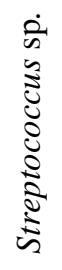 & 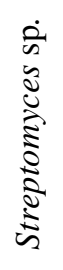 & 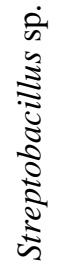 \\
\hline \multirow{3}{*}{$\mathrm{SHC}$} & $2 \mathrm{ppm}$ & + & - & + & + & + & + \\
\hline & $5 \mathrm{ppm}$ & + & - & + & + & - & - \\
\hline & $10 \mathrm{ppm}$ & + & - & + & - & - & - \\
\hline \multirow{3}{*}{$\mathrm{CA}$} & $200 \mathrm{ppm}$ & + & + & + & + & + & + \\
\hline & 500 ppm & + & + & + & + & + & + \\
\hline & $1000 \mathrm{ppm}$ & + & + & + & + & + & + \\
\hline \multirow{3}{*}{ 8-HQC } & $50 \mathrm{ppm}$ & + & - & + & - & + & + \\
\hline & 100 ppm & + & - & + & - & + & + \\
\hline & 200 ppm & + & + & + & + & - & - \\
\hline \multirow{3}{*}{$\mathrm{SHC}$} & $2 \mathrm{ppm}+\mathrm{Ox}$ & + & - & + & - & - & - \\
\hline & $5 \mathrm{ppm}+\mathrm{Ox}$ & + & - & + & + & - & - \\
\hline & $10 \mathrm{ppm}+\mathrm{Ox}$ & + & - & + & + & - & - \\
\hline \multirow{3}{*}{$\mathrm{CA}$} & $200 \mathrm{ppm}+\mathrm{Ox}$ & + & + & + & - & - & - \\
\hline & $500 \mathrm{ppm}+\mathrm{Ox}$ & + & + & + & + & - & - \\
\hline & $1000 \mathrm{ppm}+\mathrm{Ox}$ & + & + & + & + & - & - \\
\hline \multirow{3}{*}{ 8-HQC } & $50 \mathrm{ppm}+\mathrm{Ox}$ & + & - & + & - & - & - \\
\hline & $100 \mathrm{ppm}+\mathrm{Ox}$ & + & - & + & - & - & - \\
\hline & $200 \mathrm{ppm}+\mathrm{Ox}$ & + & - & + & - & - & - \\
\hline Control & & + & + & + & + & + & + \\
\hline
\end{tabular}

$\mathrm{SHC}=$ Sodium hypochlorite, $\mathrm{CA}=$ Citric acid, 8 -HQC $=8$-hydroxy Quinoline citrate and $\mathrm{Ox}=$ Oxytetracycline hydrochloride antibiotic (at $1000 \mathrm{ppm}$ ), (+) Positive growth, (-) No growth (absence of bacteria) 
Table (5): Effect of antimicrobial agents on occurrence of the associated fungal species in Asparagus aethiopicus cut stem in treated vases under natural infection.

\begin{tabular}{|c|c|c|c|c|c|c|}
\hline \multicolumn{2}{|c|}{ Treatment } & 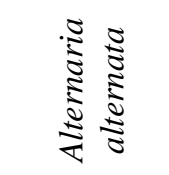 & 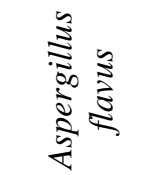 & 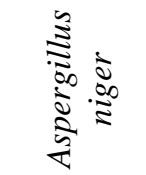 & 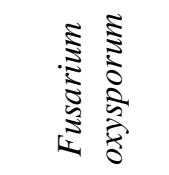 & 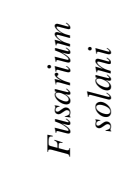 \\
\hline \multirow{4}{*}{ SHC } & $2 \mathrm{ppm}$ & $22.33^{*}$ & 15.12 & 15.06 & 25.04 & 19.35 \\
\hline & $5 \mathrm{ppm}$ & 20.51 & 14.39 & 14.46 & 26.95 & 18.92 \\
\hline & $10 \mathrm{ppm}$ & 20.31 & 11.04 & 14.74 & 25.87 & 13.09 \\
\hline & Mean & $21.05 \mathrm{~A}^{*}$ & $13.51 \mathrm{AB}$ & $14.75 \mathrm{~A}$ & $25.95 \mathrm{~A}$ & $17.12 \mathrm{~A}$ \\
\hline \multirow{4}{*}{$\mathrm{CA}$} & $200 \mathrm{ppm}$ & 21.62 & 18.52 & 16.62 & 24.16 & 19.08 \\
\hline & $500 \mathrm{ppm}$ & 16.05 & 16.75 & 16.90 & 18.03 & 19.68 \\
\hline & $1000 \mathrm{ppm}$ & 13.70 & 16.51 & 15.34 & 19.20 & 19.43 \\
\hline & Mean & $17.12 \mathrm{ABC}$ & $17.26 \mathrm{~A}$ & $16.29 \mathrm{~B}$ & $20.46 \mathrm{ABC}$ & $19.30 \mathrm{AB}$ \\
\hline \multirow{4}{*}{ 8-HQC } & $50 \mathrm{ppm}$ & 20.25 & 13.47 & 13.47 & 27.44 & 16.58 \\
\hline & 100 ppm & 21.21 & 11.95 & 13.80 & 27.27 & 13.80 \\
\hline & $200 \mathrm{ppm}$ & 18.49 & 11.71 & 15.08 & 24.51 & 13.13 \\
\hline & Mean & $19.98 \mathrm{AB}$ & $12.38 \mathrm{AB}$ & $14.12 \mathrm{~A}$ & $26.41 \mathrm{~A}$ & $14.50 \mathrm{BC}$ \\
\hline \multirow{4}{*}{ SHC } & $2 \mathrm{ppm}+\mathrm{Ox}$ & 17.40 & 9.89 & 10.07 & 20.15 & 09.89 \\
\hline & $5 \mathrm{ppm}+\mathrm{Ox}$ & 14.97 & 9.98 & 11.05 & 19.07 & 09.98 \\
\hline & $10 \mathrm{ppm}+\mathrm{Ox}$ & 10.07 & 06.36 & 06.36 & 10.07 & 03.33 \\
\hline & Mean & $14.15 \mathrm{BC}$ & $8.75 \mathrm{BC}$ & $9.16 \mathrm{~B}$ & $16.43 \mathrm{BC}$ & $7.74 \mathrm{D}$ \\
\hline \multirow{4}{*}{$\mathrm{CA}$} & $200 \mathrm{ppm}+\mathrm{Ox}$ & 18.86 & 10.47 & 14.93 & 23.62 & 12.97 \\
\hline & $500 \mathrm{ppm}+\mathrm{Ox}$ & 19.90 & 11.27 & 12.89 & 21.60 & 11.53 \\
\hline & $1000 \mathrm{ppm}+\mathrm{Ox}$ & 18.94 & 12.11 & 11.95 & 21.66 & 09.39 \\
\hline & Mean & $19.23 \mathrm{AB}$ & $11.28 \mathrm{~B}$ & $13.26 \mathrm{AB}$ & $22.29 \mathrm{AB}$ & $11.30 \mathrm{CD}$ \\
\hline \multirow{4}{*}{ 8-HQC } & $50 \mathrm{ppm}+\mathrm{Ox}$ & 13.89 & 8.33 & 11.11 & 16.67 & 11.11 \\
\hline & $100 \mathrm{ppm}+\mathrm{Ox}$ & 11.62 & 8.84 & 08.84 & 14.65 & 08.84 \\
\hline & $200 \mathrm{ppm}+\mathrm{Ox}$ & 10.53 & 3.03 & 07.50 & 10.53 & 03.03 \\
\hline & Mean & $12.01 \mathrm{C}$ & $6.73 \mathrm{C}$ & $9.15 \mathrm{~B}$ & $13.95 \mathrm{C}$ & $7.66 \mathrm{D}$ \\
\hline \multicolumn{2}{|l|}{ Control } & 22.41 & 19.14 & 16.95 & 27.81 & 19.93 \\
\hline \multicolumn{2}{|c|}{ LSD. at 0.05} & 8.75 & 7.04 & 6.75 & 9.59 & 7.05 \\
\hline
\end{tabular}

Egypt. J. Phytopathol., Vol. 47, No. 2 (2019) 
EVALUATION ACTIVITY OF SOME ANTIMICROBIAL AGENTS .. 169

3.2. Effect of antimicrobial agents on the physiological traits and vase life of A.

aethiopicus cut stems:

Foliage vase life was monitored daily until the end of the experiment, 14 days after treatment with antimicrobial agents and the numbers of days until $20 \%$ of the foliage wilting, yellowing, desiccation, graying, curling, necrosis, and leaves drop were recorded. Also, foliage weight loss and water uptake were also calculated at the end of experiment and data are presented in Table (6). It is evident from the tabulated data that all treatments succeeded to decrease weight loss and enhanced water uptake and vase life of the treated A. aethiopicus twigs and the effect was increased with increasing the concentration (Table 6). However, treatment of 8hydroxy quinoline citrate $(200 \mathrm{ppm})+$ oxytetracycline was the most effective and decreased twigs weight loss to be a low as $4.05 \%$ compared to $44.37 \%$ for the untreated control. Also, this treatment enhanced water uptake and vase life to be as high of $44.90 \mathrm{~g}$. and 14.50 days compared to $16.81 \mathrm{~g}$. and 5.44 days for the control of the previous parameters, respectively. This was followed by sodium hypochlorite $(10 \mathrm{ppm})+$ oxytetracycline hydrochloride $(1000 \mathrm{ppm})$ and citric acid at (1000 ppm) + oxytetracycline hydrochloride (1000 ppm) which showed $9.40 \%, 43.32 \mathrm{~g}$ and 14.0 days, and $26.79 \%, 40.78 \mathrm{~g}$ and 9.67 days for the previous parameters, respectively. However, treatments with antimicrobial agents only without oxytetracycline hydrochloride showed lower effect for all the previous parameters (Table 6).

4. Correlation between the bacterial and fungal reductions of treatments and the physiological traits and vase life of A. aethiopicus cut stems.

It is evident from Figure (2) that strong correlations to vase life $(r=0.85-0.96)$ were existed between the bacterial and fungal reductions exerted by the different antimicrobial agents treatments and the associated weight loss, water uptake, and vase life of A. aethiopicus cut stems, basal, dipped in the treatment solutions. The correlation types were very similar for both the bacterial and fungal reduction effect, however, there were positive correlations with vase life and water uptake, but negative correlation with cut stem weight loss (Figure 2). 
Table (6): Antimicrobial effect of agents at different concentrations on physiological traits and vase life of Asparagus aethiopicus cut stems, base dipped in treatment solutions.

\begin{tabular}{|c|c|c|c|c|c|c|c|}
\hline \multicolumn{2}{|r|}{ Treatment } & \multicolumn{2}{|c|}{ Weight loss (\%) } & \multicolumn{2}{|c|}{ Water uptake (g) } & \multicolumn{2}{|c|}{ Vase life (days) } \\
\hline \multirow{3}{*}{ SHC } & $2 \mathrm{ppm}$ & $25.36 \mathrm{ef}$ & \multirow{3}{*}{$\begin{array}{c}20.48^{*} \\
\mathrm{C}\end{array}$} & $30.47 \mathrm{j}$ & \multirow{3}{*}{$\begin{array}{c}34.42 * \\
\text { D }\end{array}$} & $06.17 \mathrm{ij}$ & \multirow{3}{*}{$\begin{array}{c}08.10^{*} \\
\mathrm{DE}\end{array}$} \\
\hline & $5 \mathrm{ppm}$ & 24.30 efg & & $35.43 \mathrm{i}$ & & $09.00 \mathrm{fg}$ & \\
\hline & $10 \mathrm{ppm}$ & $11.78 \mathrm{k}$ & & $37.36 \mathrm{gh}$ & & $09.33 \mathrm{efg}$ & \\
\hline \multirow{3}{*}{$\mathrm{CA}$} & $200 \mathrm{ppm}$ & $32.57 \mathrm{~b}$ & \multirow{3}{*}{$\begin{array}{c}31.10 \\
\mathrm{~A}\end{array}$} & 25.381 & & $06.17 \mathrm{ij}$ & \multirow{3}{*}{$\begin{array}{c}07.22 \\
\text { D }\end{array}$} \\
\hline & $500 \mathrm{ppm}$ & $30.90 \mathrm{bc}$ & & $27.32 \mathrm{k}$ & $\begin{array}{c}27.39 \\
D\end{array}$ & 07.17 hij & \\
\hline & $1000 \mathrm{ppm}$ & $29.82 \mathrm{bcd}$ & & $29.48 \mathrm{j}$ & & $08.33 \mathrm{gh}$ & \\
\hline \multirow{3}{*}{ 8-HQC } & $50 \mathrm{ppm}$ & $27.45 \mathrm{cde}$ & \multirow{3}{*}{$\begin{array}{c}24.95 \\
\text { B }\end{array}$} & $35.44 \mathrm{i}$ & & $10.83 \mathrm{cde}$ & \multirow{3}{*}{$\begin{array}{c}10.11 \\
\mathrm{C}\end{array}$} \\
\hline & $100 \mathrm{ppm}$ & $25.23 \mathrm{efg}$ & & $36.50 \mathrm{hi}$ & $\begin{array}{c}36.45 \\
\mathrm{C}\end{array}$ & $08.50 \mathrm{gh}$ & \\
\hline & $200 \mathrm{ppm}$ & $22.18 \mathrm{fg}$ & & $37.42 \mathrm{gh}$ & & $11.0 \mathrm{~cd}$ & \\
\hline \multirow{3}{*}{ SHC } & $2 \mathrm{ppm}+\mathrm{Ox}$ & $21.54 \mathrm{gh}$ & \multirow{3}{*}{$\begin{array}{c}17.76 \\
\mathrm{D}\end{array}$} & $41.57 \mathrm{~cd}$ & & 09.83 defg & \multirow{3}{*}{$\begin{array}{c}11.39 \\
\text { B }\end{array}$} \\
\hline & $5 \mathrm{ppm}+\mathrm{Ox}$ & $22.35 \mathrm{fg}$ & & $42.44 \mathrm{bc}$ & $\begin{array}{c}42.44 \\
\mathrm{~A}\end{array}$ & $10.33 \mathrm{def}$ & \\
\hline & $10 \mathrm{ppm}+\mathrm{Ox}$ & $9.40 \mathrm{k}$ & & $43.32 \mathrm{~b}$ & & $14.0 \mathrm{a}$ & \\
\hline \multirow{3}{*}{$\mathrm{CA}$} & $200 \mathrm{ppm}+\mathrm{Ox}$ & $22.44 \mathrm{fg}$ & \multirow{3}{*}{$\begin{array}{c}24.97 \\
\text { B }\end{array}$} & $38.46 \mathrm{fg}$ & & $7.33 \mathrm{hi}$ & \multirow{3}{*}{$\begin{array}{c}08.94 \\
\text { D }\end{array}$} \\
\hline & $500 \mathrm{ppm}+\mathrm{Ox}$ & $25.69 \mathrm{ef}$ & & 39.45 ef & $\begin{array}{c}39.56 \\
\text { B }\end{array}$ & $9.83 \mathrm{defg}$ & \\
\hline & $1000 \mathrm{ppm}+\mathrm{Ox}$ & $26.79 \mathrm{de}$ & & $40.78 \mathrm{de}$ & & $9.67 \mathrm{defg}$ & \\
\hline \multirow{3}{*}{ 8-HQC } & $50 \mathrm{ppm}+\mathrm{Ox}$ & $18.05 \mathrm{hi}$ & \multirow{3}{*}{$\begin{array}{c}12.65 \\
\mathrm{E}\end{array}$} & $41.56 \mathrm{~cd}$ & & $12.0 \mathrm{bc}$ & \multirow{3}{*}{$\begin{array}{c}13.28 \\
\mathrm{E}\end{array}$} \\
\hline & $100 \mathrm{ppm}+\mathrm{Ox}$ & $15.85 \mathrm{i}$ & & $42.82 \mathrm{bc}$ & $\begin{array}{c}43.09 \\
\mathrm{E}\end{array}$ & $13.33 \mathrm{ab}$ & \\
\hline & $200 \mathrm{ppm}+\mathrm{Ox}$ & $04.05 \mathrm{~h}$ & & $44.90 \mathrm{a}$ & & $14.50 \mathrm{a}$ & \\
\hline & Control & $44.37 \mathrm{a}$ & & $16.81 \mathrm{~m}$ & & $05.44 \mathrm{k}$ & \\
\hline & $\mathrm{SD}$. at 0.05 & 3.86 & 1.93 & 1.55 & 0.78 & 1.54 & 0.77 \\
\hline
\end{tabular}

$\mathrm{SHC}=$ Sodium hypochlorite, $\mathrm{CA}=$ Citric acid, 8-HQC $=8$-hydroxy Quinoline citrate and $\mathrm{Ox}=$ Oxytetracycline hydrochloride antibiotic (at $1000 \mathrm{ppm}$ ), (*) Mean of treatment

Values followed by different letter (s), for each single parameter, are significantly different at $5 \%$ level.

Egypt. J. Phytopathol., Vol. 47, No. 2 (2019) 
EVALUATION ACTIVITY OF SOME ANTIMICROBIAL AGENTS .. 171
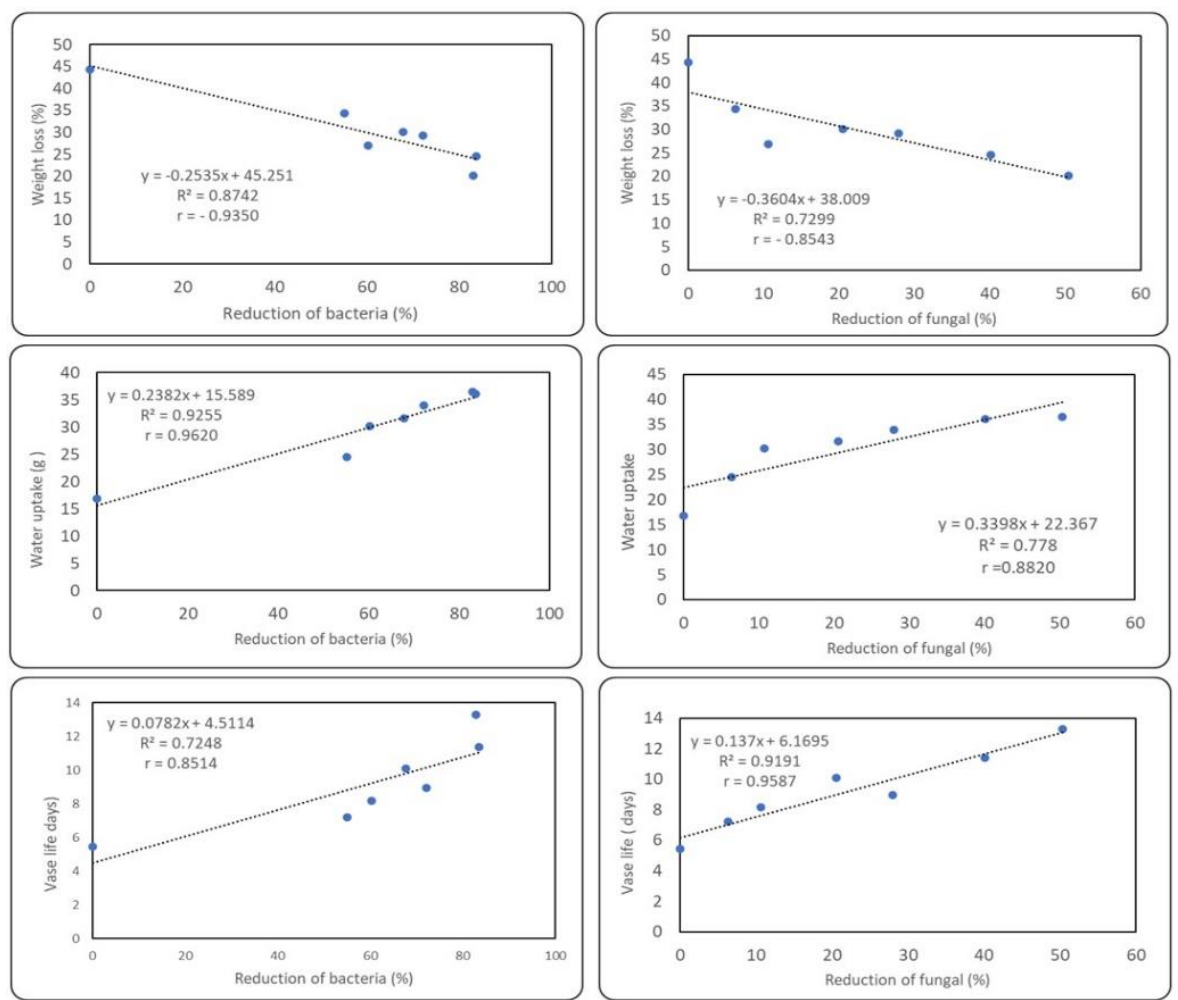

Figure (2): Correlation between the bacterial and fungal reductions of treatments and the physiological traits and vase life of Asparagus aethiopicus cut stems.

\section{Discussion}

Vase life was normally terminated when the foliage became wilted, and the stems collapsed. Poor water relations in leafy stems can be the result of microbial or physiological occlusions in the vascular system Byung-Chun et al. (2010).

In this respect, Coutinho and Wingfield (2017) and Zeiss et al. (2019) mentioned that the presence of pathogenic agents (bacterial and/or fungal ones) and their metabolites often lead to vascular siege in cut stems damaging the important cellular processes and accelerates the death of the infected stems.

In the present study, several bacterial and fungal species were found to be associated with $A$. aethiopicus cut stem wilt and its vase life. This included six 
bacterial species, i.e., Bacillus subtilis, Bacillus sp., Pseudomonas sp., Streptococcus sp., Streptomyces sp. Streptobacillus sp., and also five fungal species, i.e., Alternaria alternata, Fusarium oxysporum, F. solani, Aspergillus flavus, and A. niger. However, Bacillus subtilis, Pseudomonas sp., Alternaria alternata and $F$. oxysporum were the most frequent bacterial and fungal species. These results are in harmony with several investigators (Van-Doorn 2012; Jowkar et al., 2013; Rida et al., 2016; Coutinho and Wingfield 2017 and Sarhan et al., 2018).

The usage of some antibiotics such as oxytetracycline was commonly used to control cut stem decay in vases resulted by plant pathogens, however, this problem was not fully resolved. Also, preservative solutions (antimicrobial agents) in vase were useful for reducing the risk of such pathogens in some studies (Li et al., 2017 and Kantharaj et al., 2018).

The antimicrobial agents are chemical substances used for treatment microorganisms to destroy, deter, render harmless, or exert a controlling effect on any harmful organism, or, a group of substances including preservatives, disinfectants, germicides, antibiotics and pesticides used for the control of harmful organisms. Several antimicrobial agents such as sodium hypochlorite, citric acid and 8-hydroxyquinoline citrate are used in vase solutions in order to control decay to increase the vase life of several cut flowers (Rida et al., 2016 and He et al., 2018).

In the present study the three tested antimicrobial agents, i.e., 8-hydroxy quinoline citrate (8-HQC), sodium hypochlorite and citric acid significantly reduced number of bacterial and fungal numbers in the different vase treatments where $A$. aethiopicus cut stem basal ends were dipped and this effect was increased by increasing the antimicrobial agent concentration. However, 8-HQC at $200 \mathrm{ppm}+$ oxytetracycline hydrochloride $(1000 \mathrm{ppm})$ showed reduction percentages of 84.29 and $51.72 \%$ in bacterial and fungal numbers, respectively. Also, sodium hypochlorite at $10 \mathrm{ppm}+$ oxytetracycline hydrochloride $(1000 \mathrm{ppm})$ recorded bacterial and fungal reductions that reached 85.25 and $42.44 \%$, respectively. This was followed by citric acid $(1000 \mathrm{ppm})+$ oxytetracycline hydrochloride $(1000 \mathrm{ppm})$ which showed 83.31 and $28.32 \%$, reductions in bacteria and fungi numbers. However, antimicrobial agent treatments without oxytetracycline hydrochloride showed lower reduction effect than antimicrobial agents amended with oxytetracycline hydrochloride. These results are in harmony with those recorded by Erin et al. (2014), Hema et al. (2015), Malakar et al. (2017) and Balieiro et al. (2018).

The effect of 8-HQC may be due to that 8-hydroxyquinoline contains a hydroxyl group which has a $\mathrm{pH}$ value that could affect the bacterial and fungal growth (Malakar et al., 2017). Also, sodium hypochlorite contains chlorine atoms that may enhance the efficacy of that compound. Also, citric acid effect probably

Egypt. J. Phytopathol., Vol. 47, No. 2 (2019) 
EVALUATION ACTIVITY OF SOME ANTIMICROBIAL AGENTS .. 173

due to its $\mathrm{pH}$ effect, in addition to the presence of the effective antibiotic oxytetracycline hydrochloride (Hema et al., 2015).

On the other hand, all antimicrobial agents treatments succeeded to decrease weight loss and enhanced water uptake and vase life of the treated A. aethiopicus twigs and this effect was increased with increasing the concentrations of the antimicrobial agents. Meanwhile, treatment with 8-HQC $(200 \quad \mathrm{ppm}) \quad+$ oxytetracycline (1000 ppm) was the most effective and decreased twigs weight loss to be a low as $4.05 \%$ compared to $44.37 \%$ for the untreated control. Also, this treatment enhanced water uptake and vase life to be as high of $44.90 \mathrm{~g}$ and 14.50 days compared to $16.81 \mathrm{~g}$ and 5.44 days for the control of the previous parameters, respectively. This was followed by sodium hypochlorite $(10 \mathrm{ppm})+$ oxytetracycline hydrochloride $(1000 \mathrm{ppm})$ and citric acid at $(1000 \mathrm{ppm})+$ oxytetracycline hydrochloride (1000 ppm) treatments.

Meanwhile, strong correlations to vase life $(r=0.85-0.96)$ were existed between the bacterial and fungal reductions exerted by the different antimicrobial agents treatments and the associated weight loss, water uptake, and vase life of $A$. aethiopicus cut stems basal dipped in the treatment solutions. The correlation types were very similar for both the bacterial and fungal reductions, however, there were positive correlations with vase life and water uptake, but negative correlation with cut stem weight loss.

These results are in consistence with Van-Doorn (2012) and Younis et al. (2018) who indicated that accompanied bacterial and fungal proliferation in vase solutions lowering their lifetime and causing insufficient water uptake due to physical blockage of xylem vessels as vessels has been infected. Consequently, the obtained enhancement for physiological aspects and vase life may be due to increasing water uptake that led to the longevity of the leafy stems. This is, also, in harmony with Elgimabi and Sliai (2013) who showed that the vase life of Taif rose cut flowers was prolonged by 8-HQS treatments. In addition, Farahat et al. (2014) reported that leaf water content was the highest in a solution containing $125 \mathrm{ppm} 8$-HQS.

\section{References}

Al-Jaradi, A.; Al-Mahmooli, I.; Janke, R.; Maharachchikumbura, S.; Al-Saady, N. and Al-Sadi, A.M. 2018. Isolation and identification of pathogenic fungi and oomycetes associated with beans and cowpea root diseases in Oman. PeerJ 6: e6064 (Microbiology).

Amin, O.A. 2017. II-Effect of some chemical treatments on keeping quality and vase life of cut Chrysanthemum flowers. Middle East Journal of Agriculture Research, 6(1): 221-243. 
Balestra, G.M.; Agostini, R.; Bellincontro, A.; Mencarelli, F. and Varvaro, L. 2005. Bacterial populations related to gerbera (Gerbera jamesonii L.) stem break. Phytopathologia Mediterranea, 44(3): 291-299.

Barnett, H.L. and Hunter, B.B. 1986. Illustrated Genera of Imperfect Fungi. Burgess Publishing Company, Minnesota USA. 241 pp.

Benson, H.J. 2002. Microbiological Application a Laboratory Manual in General Microbiology. $8^{\text {th }}$ Edition. McGraw Hill. 478 pp.

Braithwaite, M.; Hill, C.F.; Ganev, S.; Pay, J.M.; Pearson, H.G. and Alexander, B.J.R. 2006. A survey of sub-tropical nursery plants for fungal diseases in Northland. New Zealand Plant Protection, 59:132-136.

Balieiro, B.T.S.; Júnior, M.A.; Vieira, de Souza, A.V.; de O. Moreira, S.M.; do Nascimento, A.H.C.; Júnior, W.S.E. and de Souza, G.R.B. 2018. Postharvest life of cut chrysanthemum flowers as affected by citric acid, boric acid and salicylic acid. Amazonian Journal of Plant Research, 2(1): 127-144.

Byung-Chun, I.; Myoung-Kap, C.; Hye-Jin, B. and Ki-Cheo, I.S. 2010. Effect of vase water temperature and leaf number on water relations and senescence of cut roses. Kor. J. Hort. Sci. Technol., 28(4): 609-617.

Coutinho, T.A. and Wingfield, M.J. 2017. Ralstonia solanacearum and $R$. pseudosolanacearum on Eucalyptus: Opportunists or primary pathogens. Front Plant Sci., 8: 761.

Elgimabi, M.N. and Sliai, A.M. 2013. Effects of preservative solutions on vase life and postharvest qualities of Taif rose cut flowers (Rosa damascene cv. Trigintipetala). American-Eurasian J. Agric. Environ. Sci., 13: 72-80.

Erin, P.M.; Dole, J.M. and Barnes, J. 2014. Refining postharvest handling procedures increased cut rose vase life. Hurt Technology., 24: 676-685.

Farahat, M.M.; Abd-El-Aziz, N.G.A.; Hashish, Kh.I. and Gaber, A. 2014. Postharvest physiology and vase life of rose (Rosa hybrid L. cv. Grand Prix) cut flowers as influenced by using sucrose and some chemical treatments. Middle East J. Agric. Res., 3(4): 815-819.

Ferrante, A.; Alberici, A.; Antonacci, S. and Serra, G. 2007. Effect of promoter and inhibitors of phenylalanine ammonialyase enzyme on stem bending of cut gerbera flowers. International Conference on Quality Management in Supply Chains of Ornamentals. 755: 471-476.

Ferreira, J.H.S; Matthee, F.N. and Thomas, A.C. 1991. Biological control of Eutypa lata on grapevine by an antagonistic strain of Bacillus subtilis. Phytopathology, 81: 283-287.

Egypt. J. Phytopathol., Vol. 47, No. 2 (2019) 
EVALUATION ACTIVITY OF SOME ANTIMICROBIAL AGENTS .. 175

Fung, D.Y.C. 2009."Viable Cell Counts". Bioscience International. Retrieved September. 25, 2016.

Gandipilli, G. and Geddada, E.R. 2018. Ethnobotanical profiling of Asparagus aethiopicus L. Tropical Plant Research, 5(1): 116-120.

Harrigan, W.F. and McCance, M.E. 1996. Laboratory Methods in Microbiology. Academic Press, INC, (London) LTD. Pp 361.

Hashemabadi, D.; Torkashvand, A.M.; Kaviani, B.; Bagherzadeh, M.; Rezaalipour, M. and Zarchini, M. 2015. Effect of Mentha pulegium extract and 8- hydroxyl quinoline sulfate to extend the quality and vase life of rose (Rosa hybrid) cut flower. J. Environmental Biology, 36: 215-220.

He, Y.; Qian, L.; Liu, X.; Hu, R.; Huang, M.; Liu, Y. and Zhu, H. 2018. Graphene oxide as an antimicrobial agent can extend the vase life of cut flowers. Nano Research, 11(11): 6010-6022.

Hema, P., Bhaskar, V.V.; Bhanusree, M.R. and Suneetha, D.R.S. 2015. Studies on the effect of different chemicals on the vase life of cut Gerbera (Gerbera jamesonii bolux ex. Hook) Gerbera cv. Alppraz. Plant Archives, 15(2): 963-966.

Ichimura, K.; Yoshioka, S. and Yamada, T. 2016. Exogenous mannitol treatment stimulates bud development and extends vase life of cut snapdragon flowers. Postharvest Biol. Technol., 113: 20-28.

Jowkar, M.M.; Khalighi, A.; Kafi, M. and Hassanzadeh, N. 2013. Nano silver application impact as vase solution biocide on postharvest microbial and physiological properties of "Cherry Brandy". JFAE., 11: 1045-1050.

Jowkar, M.M.; Kafi, M.; Khalighi, A. and Hasanzadeh, N. 2012. Evaluation of aluminium sulfate as vase solution biocide on postharvest microbial and physiological properties of 'Cherry Brandy' rose. Ann. Biol. Res., 3(2):11321144.

Kampowski, T.; Mylo, M.D.; Poppinga, S. and Speck, T. 2018. How water availability influences morphological and biomechanical properties in the oneleaf plant Monophyllaea horsfieldii. Royal Society Open Science, 5:171076.

Kantharaj, Y.; Naik, B.H.; Prashanth, S.J.; Sreenivas, K.N.; Seetharaman, G.K.; Sangama and Shivashankar, K.S. 2018. Standardization of different chemicals on the vase life of cut Gerbera (Gerbera jamesonii) cv. Julia. International Journal Pure Applied Biosci., 6(1): 849-855.

Li, J.; Zhao, G.Z.; Huang, H.Y.; Qin, S.; Zhu, W.Y.; Zhao, L.X.; Xu, L.H.; Zhang, S.; Liand, W,J.; Strobel, G. 2012. Isolation and characterization of culturable endophytic actinobacteria associated with Artemisia annиa L. Antonie van Leeuwenhoek, 101:515-527. 
Li, H.; Liu, J.; Luo, Z.; Joyce, D. and He, S. 2017. Nano-silver treatments reduced bacterial colonization and biofilm formation at the stem ends of cut gladiolus 'Eerde' spices. Postharvest Biol. Technol., 123: 102-111.

Malakar, M.; Acharyya, P. and Biswas, S. 2017. Effect of certain chemicals on postharvest life of some cut foliages. International Journal of Agriculture, Environment and Biotechnology, IJAEB., 10(2): 199-207.

Naing, A. H.; Win, N.M.; Han, J-S.; Lim, K.B. and Kim, C.K. 2017. Role of Nanosilver and the Bacterial Strain Enterobacter cloacae in Increasing Vase Life of Cut Carnation 'Omea'. Front. Plant Sci., 8:1590.

Rafi, Z.N. and Ramezanian, A. 2013. Vase life of cut rose cultivars 'Avalanche' and 'Fiesta' as affected by Nano-Silver and S-carvone treatments. South African Journal of Botany, 86: 68-72.

Reynolds, J. 2015. "Serial Dilution Protocols". American Society for Microbiology, ASM Microbe Library. http://www.microbelibrary.org/component/resource/laboratorytest/2884-serial-dilution-protocols.

Rida, M.F.; Rehab, S. and Salem, M.Z.M. 2016. Effect of Schinus terebinthifolius extracted oil, 8- hydroxyquinoline sulphate and citric acid on the lonevity and quality of Calla lily cut flowers. J. Adv. Agric. Res., 21(2): 348-358.

Safeena, S.A.; Thangam, M. and Singh, N.P. 2019. Conservation and evaluation of different cut foliage species comprising Pteridophytes (Ferns and Fern Allies) of West Coast Regions of India. Journal Indian Soc. Coastal Agriculture Research, 37(1): 3-13.

Safeena, S.A.; Jayanthi, R.; Raju, B.; Jaganath, S.; Ramakrishna, B.M. and Parama, V.R.R. 2014. Effect of pulsing on postharvest longevity of cut leaves of lace Fern/Bridal Fern (Asparagus setaceus syn. Plumosus). Proc. Natl. Acad. Sci., India, Sect. B Biol. Sci., 84(3): 735-742.

Sarhan E.A.D.; El-Far, E.M.M. and Ebrahiem, A.M.Y. 2018. Systemic resistance in snap bean (Phaseolus vulgaris L.) elicited by some chemicals and biotic inducers against white mold disease caused by (Sclerotinia sclerotiorum). Egypt J. Phytopathol., 46(2): 61-84.

Shabanian, S.; Esfahani, M.N.; Karamian, R. and Tran, L.S.P. 2018. Physiological and biochemical modifications by postharvest treatment with sodium nitroprusside extend vase life of cut flowers of two gerbera cultivars. Postharvest Biol. Technol., 137: 1-8.

Snedecor, G.W. and Cochran, W. 1989. Statistical Methods, Eighth Edition, Iowa State University Press, USA. 491 pp.

Egypt. J. Phytopathol., Vol. 47, No. 2 (2019) 
Sneh, B.; Burpee, P. and Ogoshi, A. 1991. Identification of Rhizoctonia species. A.P.S. Press, St. Paul, Minnesota, USA. 133 pp.

Song, W.; Zhou, L.; Yang, C.; Cao, X.; Zhang, L. and Liu, X. 2004. Tomato Fusarium wilt and its chemical control strategies in a hydroponic system. Crop Prot., 23: 243-247.

Vakalounakis, D.J. and Fragkiadakis, G.A. 1999. Genetic diversity of Fusarium oxysporum isolates from cucumber: Differentiation by pathogenicity, vegetative compatibility and RAPD fingerprinting. Phytopathology, 89: 161-168.

Van-Doorn, W.G. 2012. Water relations of cut flowers: An update. In: Horticultural reviews, Janick J. Wiley, Hoboken. 40: 55-106.

Younis, A.; Akhtar, M.S.; Riaz, A.; Zulfiqar, F.; Qasim, M.; Farooq, A.; Tariq, U.; Ahsan, M. and Bhatti, Z.M. 2018. Improved cut flower and corm production by exogenous Moringa leaf extract application on gladiolus cultivars. Acta Sci. Pol. Hortorum. Cultus., 17: 25-38.

Younis, A.; Zahir, Z.; Riaz, A.; Tariq, U. 2014. Microbial inoculation increases the nutrient uptake efficiency for quality production of Gladiolus grand floras. Pak. J. Agri. Sci., 51: 875-880.

Zeiss, D.R.; Mhlongo, M.I.; Tugizimana, F.; Steenkamp, P.A. and Dubery, I.A. 2019. Metabolomic profiling of the host response of tomato (Solanum lycopersicum) following infection by Ralstonia solanacearum. Int. J. Mol. Sci., 20(16): 3945.

Corresponding author: Abdel-Rahman, T.F.M.

E-mail: ttaghreedfekry@gmail.com

(Received 20/10/2019;

in revised form 17/11/2019) 


\section{تقييم فعالية بعض المضادات الميكروبية فى خفض الحمل

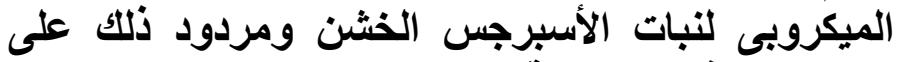 طول العمر فى المز هرية لمئية \\ تغريد فكري محمد عبد الرحمن}

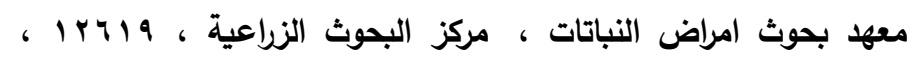

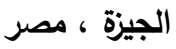

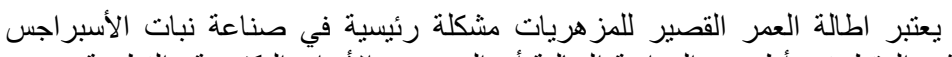

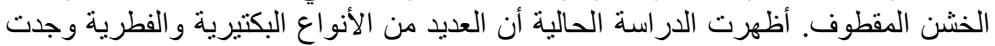

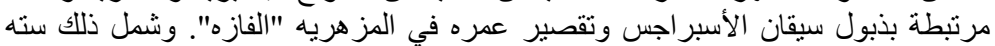

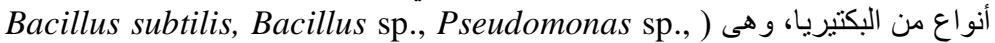
atreptococcus sp., Streptomyces sp. Streptobacillus sp.,

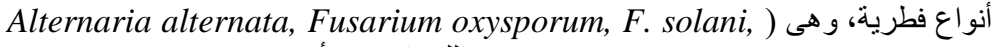
Bacillus subtilis, ) ومع ذللك، كانت الأنواع (Aspergillus flavus, and A. niger هي الأنواع (Pseudomonas sp., Alternaria alternata and F. oxysporum

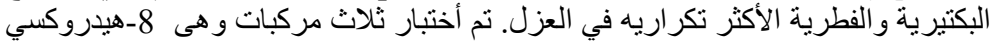

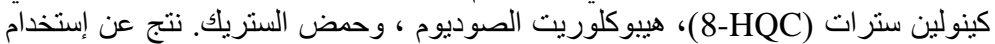

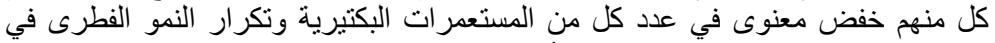

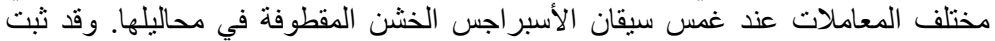

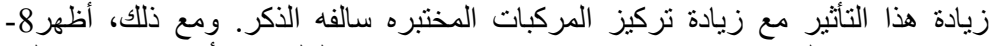

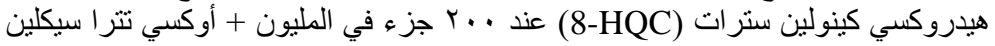

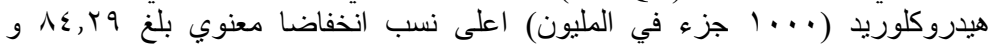

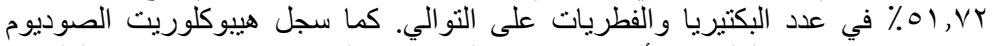

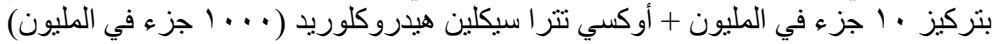

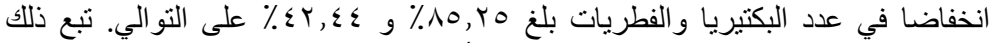

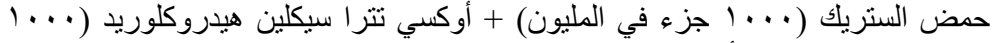

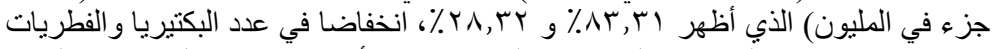

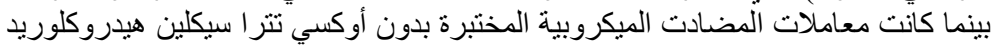

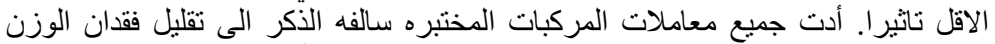

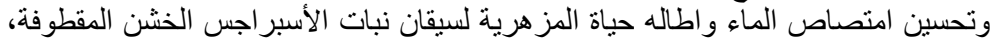

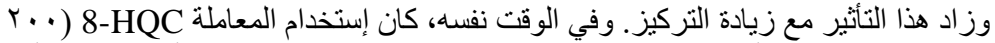

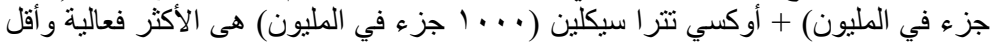

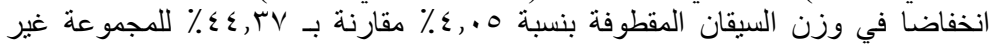

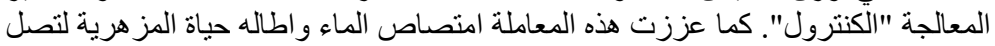

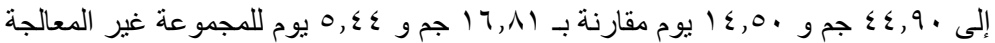

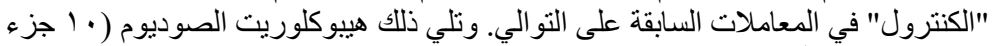

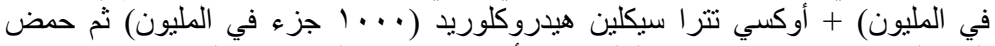

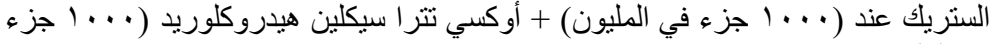

$$
\text { في المليون). }
$$

